\title{
Empowerment and Disempowerment of Workfare Volunteers: A Diachronic Approach to Activation Policy in the Netherlands
}

\author{
Thomas Kampen* and Evelien Tonkens** \\ *University for Humanistic Studies, Utrecht, The Netherlands \\ E-mail: t.kampen@uvh.nl \\ **University for Humanistic Studies, Utrecht, The Netherlands \\ E-mail: e.tonkens@uvh.nl
}

This article focuses on experiences of welfare recipients summoned to do volunteer work. Proponents of 'workfare volunteerism' argue that it leads to empowerment and employability while critics dismiss it as disempowering, stigmatising, and disciplining. Our longitudinal qualitative inquiry into experiences of sixty-six 'workfare volunteers' in the Netherlands shows how experiences of disempowerment or empowerment are dependent on caseworker approaches as well as on time. Disempowerment can turn into empowerment when an individual's past is considered, but can revert to disempowerment if changing needs go unrecognised. These findings have broader implications for debates on activating policies. They point to the need for diachronic approaches, which reflect the changing experiences of target groups over time and adaption of policies and caseworker approaches that respond to their clients' changing needs and self-understanding.

Keywords: Workfare, mandatory volunteering, discipline, empowerment, welfare state reform.

\section{Introduction}

Policies to re-integrate welfare recipients into the labour market are prominent within the strategies of the 'activating welfare state' (Goul Andersen et al., 2005; Serrano Pascual, 2007) or 'enabling state' (Gilbert and Gilbert, 1989; Gilbert, 2002) to encourage 'active citizenship' (Kampen et al., 2013). This 'activation' of welfare recipients entails a shift in practice and discourse from collective and individual rights to individual empowerment and responsibilities. Governments no longer guarantee citizens financial security over their lifetimes but make benefits conditional on (finding) paid work (Serrano Pascual and Magnusson, 2007). If citizens claim rights without accepting responsibilities, it is argued, this encourages passivity and dependence on the state. Only when rights depend on the fulfilment of obligations can citizens be expected to become responsible, empowered 'active citizens' (Mead, 2008).

The turn towards activation of welfare recipients has been the subject of much scholarly criticism and debate. While some argue it contributes to the empowerment, employability, and responsibility of welfare clients (Crick, 2000; Soupourmas and Ironmonger, 2002; Roberts and Devine, 2004), others maintain that it is disempowering, stigmatising (Patrick, 2017), and disciplining (Cruikshank, 1999; Warburton and Smith, 
2003; Breitkreuz, 2005; Skevik, 2005; Fuller et al., 2008). This article focuses on an extreme case of activation policy: the obligation for welfare recipients to do volunteer work to qualify for benefits, which we call 'workfare volunteering' (Kampen et al., 2013).

By focusing on workfare volunteering, both praise and criticism of activation are put to the test. Earlier research has shown that volunteer work empowers people by giving them a sense of purpose, satisfaction, and (self)confidence (McClure, 2000; Thoits and Hewitt, 2001; Cockram, 2002). On the other hand, being obliged to behave prosocially may be an inherently disempowering experience (Sobus, 1995).

In what follows, we first outline the approaches to workfare volunteerism that prevail in the literature and introduce our research question. We then present our methods and empirical findings based on qualitative research among sixty-six Dutch workfare clients. In the concluding section we answer our research question and point to the theoretical implications of our findings.

\section{Debating workfare volunteerism: empowerment versus disempowerment}

Scholars strongly disagree on the implications of conditionality, workfare in general, and workfare volunteering in particular. The disagreements mostly come down to qualifying these policies as either empowering or disempowering.

Lawrence Mead (2008) maintains that conditionality would empower welfare clients. Mead believes that the majority of the worst-off people do not act in the interest of the collective unless they are forced. He believes that enforced lifestyle changes will improve people's capabilities to improve their life chances. He therefore proposes to make benefits conditional on behavioural requirements. In his view, demonstrating a work ethic is the key requirement. Conversely, research into the experiences of various vulnerable groups shows that increased conditionality disempowers welfare clients (Edmiston et al., 2017) as well as other groups, like asylum-seekers and refugees (Dwyer et al., 2016). Welfare clients experience conditionality as dehumanising, because it devalues and undermines their societal contributions, both in interactions with welfare institutions and in their daily lives (Edmiston, 2017; Garthwaite, 2017; Povey, 2017).

Critical research on workfare policies qualify them as 'disciplining', often inspired by the work of Michel Foucault. Foucault has illuminated how power disciplines subjects by invoking positive feelings such as desire, pleasure and empowerment (Dean 1999; Foucault, 2003; Miller and Rose, 2008). From this perspective, the experience of empowerment would be proof of discipline as 'productive' power; feeling empowered by workfare would be indicative that power has 'creeped under their skin' (Cruikshank, 1999). McDonald and Marston (2005) argue that (disciplining) workfare policies can be experienced as empowering, but are disempowering nevertheless; welfare clients are first made to feel unworthy and ashamed for being dependent on welfare, and then liberated by way of workfare.

Most researchers who focus more specifically on workfare volunteering are critical on the obligation to volunteer. The obligation to volunteer would disempower people by making them feel dependent and controlled (Goul Andersen, 2002), disrupting their sense of agency (Owen, 1996; Bessant, 2000) and autonomy (Warburton and Smith, 2003). Coercion also undermines positive feelings towards the community, thereby discouraging 
active contribution (Warburton and Smith, 2003) as well as internalisation of altruism or responsibility (Sobus, 1995; Stukas et al., 1999; Yeatman, 2000; Van Echteld and Josten, 2012). Being forced to volunteer would also reduce people's future willingness to volunteer (Clary et al., 1998; Stukas et al., 1999). Others are critical about workfare volunteering because of the disempowering effects of a lack of choice (Warburton and Smith, 2003; Levy, 2006) and voice (Knijn and Van Berkel, 2003).

Nevertheless, some studies point to empowering effects of workfare volunteerism. Volunteering can bolster welfare recipients' confidence and sense of autonomy (Cohen, 2009; Koen, 2013). Recognition from outside the labour market alleviates their social marginality (Fuller et al., 2008). Volunteer work would improve their employability (Cameron, 1997; Cress et al., 1997; Reitsma-Street et al., 2000) and help them to access new networks and accumulate social capital (Cox, 1998; Crick, 2000; Soupourmas and Ironmonger, 2002; Roberts and Devine, 2004).

In this article, we aim to critically examine empowering as well as disempowering effects of workfare volunteerism. We analyse the experiences with volunteering as well as the interaction between welfare clients and their caseworkers. Our research question is: under which conditions do welfare recipients experience workfare volunteerism as empowering and/or disempowering?

Answering this question calls for an analysis that is attentive to the temporal dimension of workfare volunteerism as well as to interactions between welfare recipients and caseworkers. Attention to time is important because the experience of (dis)empowerment may change over time. Especially when including the experiences with volunteer work as well as case management it is important to do this longitudinally, since both happen successively. There are few examples of longitudinal studies into the experiences of welfare clients who are subject to conditionality. Ruth Patrick $(2014,2017)$ analysed the experiences of benefit claimants over two to five years. Patrick has tracked their aspirations and shows that people on welfare want to work, but face all kinds of barriers. Being made responsible for not overcoming these barriers adds insult to injury. Despite setbacks and challenges in their efforts to secure work, welfare clients' determination to leave benefits and find paid work endured. What did change, over time, was their selectivity: over time, people tended to become less selective, and more ready to accept any job.

It is striking that most of the studies mentioned above - which argue that workfare volunteering is either empowering or disciplining - hardly pay attention to interaction between welfare recipients and caseworkers. When there are a few studies that do, they focus on how case workers approach clients and find for instance positive effects of clear communication and personalized attention (Bloom et al., 2003). Hall et al. (2012) focus on such a positive effect by showing that caseworkers' respectful and understanding approach tends to evoke reciprocal reaction of respect from clients towards caseworkers. Other studies mostly come up with rather general findings. Kjørstad (2005: 391) notes that case workers manage to handle contradictory demands and develop 'practical wisdom of interaction'. Nothdurfter finds that 'interaction between frontline workers and clients is a crucial element in the context of activation' but 'its critical aspects and professional challenges remain rather underexposed, creating a vacuum of professional debate' (Nothdurfter, 2016: 435). With this article, we aim to contribute to filling up this vacuum. 


\section{Methods}

To empirically examine how welfare recipients experience workfare volunteerism, we held 125 in-depth interviews with sixty-six individuals in five Dutch cities. Previously known for its generous benefits, the Netherlands has developed into one of the most conditional welfare states in the world (Becker, 2000; Nannestad, 2007) with broad public support for policies that emphasise the duties of welfare recipients (Veldheer et al., 2012; Van Houwelingen et al., 2014). We find similar policies in the UK (Wiggan, 2015; Whitworth, 2016) and Australia (Warburton and Smith, 2003).

We relied on the willingness of municipalities and respondents to participate in our research. As welfare recipients must inform their caseworkers when they begin volunteer work, municipalities were able to produce lists of workfare volunteers. On our request, municipalities sent our letter to 218 people, inviting them to participate in our research. In order to prevent bias, the letter was printed on our universities' letterhead. The letter requested them to contact the municipality if they did not want to be approached by a researcher, which twenty-four people did. We randomly selected informants from the remaining 194 and contacted them. In doing so, we sought to include in our sample maximum variation in age (twenty-eight to sixty-four years), ethnic background (forty-nine Dutch, six Moroccan, four Turkish, one Iranian, one Iraqi, one Chinese, one Surinamese, one Dominican, one Polish and one Romanian), gender (forty men, twenty-six women), years of former employment (zero to forty years), duration of unemployment (two to thirty-three years) and volunteer sector (neighbourhood: ten; cultural: nine; educational: twelve; advocacy: ten; care: fifteen). Examples of the volunteer work that was performed are: assisting at the information centre on neighbourhood renewal, volunteering as an attendant at a museum, reading to children at an after school care facility or playing games with the residents of an elderly day care. Thirty (of the sum total of 194) people did not answer the phone and ninety-eight were unwilling to participate, mainly due to lack of interest or research fatigue. We held in-depth semi-structured interviews with the remaining sixty-eight individuals. Although the non-response is unlikely to alter our findings - reasons for not participating that people gave us over the phone did not bear on how people experienced volunteer work or their relationships with caseworkers - it does place limits on generalisability to a larger population.

In our interviews, we asked people about past and current experiences with paid work, and with living on welfare, re-integration, and volunteer work. We also discussed what they expected from doing volunteer work and from those around them, including volunteer organisations, other volunteers, welfare officials, and employers.

The interviews took place between 2009 and 2013. We tried to talk to all informants two or three times - with six months to a year in between - to observe how their experiences with and expectations of workfare volunteering and caseworkers had changed over time. When we approached them for the second interview, one had moved abroad, while the lives of some had seriously deteriorated. We were very sorry to find out that one person was deceased, one had been admitted to a mental health institution, and one was in rehab. This illustrates the vulnerable situation of people on welfare and how social rights underpin human wellbeing (Dean, 2015). We have taken this vulnerability into account throughout the course of our research, for instance by being sensitive to our respondents' wishes regarding time and place for an interview. 
Thirty-one of the remaining sixty-two persons immediately agreed to a second interview; nineteen of them were initially hesitant, considering an interview as too confrontational (because their lives did not proceed as hoped) or unnecessary (because nothing had changed). We nevertheless managed to convince nine out of these nineteen hesitating respondents to be interviewed again by, first, making clear that we respected their decision and, second, explaining to them that their stories were in any case valuable to our research. All in all, we interviewed forty (thirty-one plus nine) respondents for a second time. We believe selection bias to be negligible, since those we did manage to interview a second time expressed similar reservations (as those who did not want to be interviewed again): some experienced it as confrontational to be approached again since their situation had not changed, while others also had doubts about the necessity of a second interview, but agreed anyway.

Of these forty respondents, twenty-one could not be interviewed a third time, because they had changed phone numbers (two), had reached retirement age (three) felt research fatigue (five) or saw it as too confrontational (eleven). The remaining nineteen respondents were willing to have a third interview. We tried to limit the risk of selection bias by asking those who agreed to a third interview about their considerations for granting our request. While most of them also felt the repeat interviews to be confrontational, they prioritised our research over these feelings.

All interviews were transcribed from audio files and analysed with the qualitative data software program Atlas.ti. We paid special attention to workfare volunteers' emotions as well as views about their rights and responsibilities, and specifically focused our analysis on their experiences with and expectations of caseworkers. Below we present our key empirical findings through the discussion of exemplary cases. All informants in this article are referred to with pseudonyms.

\section{Neglect of the past}

How do welfare clients experience the request to do volunteer work? Past experiences proved crucial to how unemployed citizens experienced this request. First, most respondents felt that their life was somehow on the wrong track, that their personal values and goals in life had been lost. They suffered from what we dubbed a 'violated life story' (Kampen, 2014). They felt neglected, missing attention to their personal past pains and future goals. Before responding to some volunteer job on offer, they first needed this attention.

When welfare clients' reasons for not doing paid or volunteer work were not taken seriously they felt disempowered. Ingrid (forty-five) for example did not want her own children to be home alone at lunch, as she herself had been raised in a broken family where attention was lacking. She therefore did not actively look for a job. But her caseworkers had no eye for how her past experiences structured her present choices.

Like they said, 'you can't do it yourself, because you proved not to be able to for a long time, so that's why we're doing it for you.' ... But they didn't ask me why. . . I I have my reasons.

Welfare clients also felt disempowered when caseworkers did not take the time to look at their situation. Esther (twenty-eight) felt that she was 'on the wrong track' and that it would take time to figure out how to improve her situation: 
They are hired to get you to work as quickly as possible, but it is actually more important to examine what people really want. And how people ended up on the wrong track, like me.

Lack of attention for how they feel about these past experiences was experienced as disempowering. Angie (forty-eight) told us she had been struggling with mental health problems after losing her job. She felt she needed to come to terms with her current problems before moving ahead:

They say: 'But if you get your benefit and you have something to do you're happy, right? Then it's okay, right?' No! There is a whole range of negative emotions that have accumulated that needs some attention first. ... They should be solved first, before thinking of prospects.

Misrecognition of past achievements was also disempowering to the welfare clients we interviewed. Paul (forty-four) was proud of having been a manager for twenty years. But four years of unemployment had fuelled his loneliness as well as a drinking problem. The one thing he held on to that sustained his hopes for a better future was his experience as a manager. He felt that his caseworkers misrecognised this:

When I say, 'I am a manager', they think I'm a neighbourhood manager, you know. ... They do not understand what my training is. They do their job, standard procedures. They have to wade through a file and then see if they can find something appropriate, but the rules are not made for me.

In general, caseworkers' lack of selectivity when suggesting a voluntary activity was experienced as a neglect of one's past. Jasper (fifty-one) explained: 'To them, it does not really matter what kind of work it is, as long as it is work. ... What I did or want is not important.'

Interactions with caseworkers were crucial here. When discussing potential activities with case workers, welfare clients wanted to be recognised for their past experience, troubles, and achievements. Feelings of neglect were often amplified in what welfare clients experienced as an undignified, bureaucratic approach. Patrick (fifty), for example, had been working in construction before he became unemployed due to back problems. He described himself as a 'loyal employee' who was always on time and worked extra hours when needed. Living on welfare is all too easy and boring, he told us. He was used to working hard, and although he had not given up on himself, he felt that others had done so. Patrick had tried to contact his caseworker for months, waiting for her to return his calls. Finally he received a formal letter about the workfare volunteer policy, mentioning the rules of compliance. To Patrick the letter proved to be neglect for his loyalty. This enraged him:

Before she [the caseworker] starts, she sums up all the regulations: what you can expect when you don't comply. I tell her: 'You better not do this again because then I will never ever come back here. Then I rather receive no benefit at all and return to unruly practices'.

Similarly, Angie (forty-eight) remembered that her caseworker had asked her in a bureaucratic manner, 'Do you do volunteer work?'. For Angie this felt as neglect of her past troubles: 
At that time I was not. I was not ready for it. 'Well', she said then, 'I will check in a year if you've found something'. The very word 'check', that alone is enough. ... Then things immediately go wrong.

Hence, the way caseworkers present the request to do volunteer work matters greatly. Welfare clients feel that caseworkers that request them to volunteer often neglect their past. They feel that their reasons, emotions, problems, and experience are set aside as irrelevant. When the request is presented in this way, they feel disempowered.

\section{Restoring a violated life story}

Being requested to volunteer can also be an empowering experience. When caseworkers approached welfare clients as unique persons with their individual histories, challenges and hopes for the future, we observed that they reacted much more positively to the request to do volunteer work. These types of requests empowered them by disrupting their feelings of worthlessness and humiliation, and by reigniting hope.

When caseworkers had taken the time to listen to the violated life story, they often suggested an activity that offered welfare clients an opportunity to make up for their past mistakes. Simon (fifty-nine), previously a museum attendant, was fired after losing his temper with a visitor who had, in his eyes, disrespected him. After listening to his violated life story, his caseworker understood that Simon wanted to prove he could still be a polite and competent museum attendant. His case manager helped him find a volunteer job at another museum. For Simon, this was an empowering experience, since it allowed him to show how wrong his former employer was to dismiss him and thereby restore his violated life story. He told us: 'Everyday I think to myself: "you see? I'm still here!"'.

Similarly, when volunteer work allowed welfare clients to restore their violated life story by regaining respect, this was also a empowering experience. Jan (forty-five), a former bar owner, had a cafe in the centre of his hometown with a large sunny terrace. When the municipality decided to build a museum, a shadow fell over his terrace and he went bankrupt. The bankruptcy made Jan feel worthless. After years of living on welfare his caseworker helped him to find a volunteering job at a homeless shelter, ordering the food and running the kitchen, just as he had done in the past. His colleagues' appreciation of his experience as a bar owner helped him to retrieve some of the respect he had earned in the past.

Tim (fifty-three), a former scientist who had lost his job and friends after litigating with his ex-wife over the custody of their children, remembered his caseworker telling him:

We have to think of something that suits you. You're not a business-type of guy, you told me. But you do like education. There are institutions in the city that provide tutoring to students. They are looking for enthusiastic people. Why don't you offer your services there?' I do not feel forced to engage in volunteering the way other people do.

Although Tim was in the end obliged to accept an activity, he did not experience it as an imposition. He felt empowered since his caseworkers found volunteer work that helped 
him to overcome his violated life story. The activity - tutoring - had personal meaning to him. It became a way of making up for seeing his children less often following his divorce.

When welfare recipients felt that they were treated respectfully, even pressure could be empowering. This was the case with the small number of interviewed welfare recipients with anxiety disorders. For them, some pressure actually demonstrated the caseworker's understanding of their problems to move forward. Omar (fifty), for example, had developed agoraphobia due to his traumatic wartime past and was now trapped between his fear of going outside and his fear of developing other psychological problems by staying indoors all day. He explained: 'If there is anything that gives me a push, maybe I will feel better, I don't know, but I have to try'. Other hesitant welfare recipients confirmed that they may need 'a swing in the right direction' or sometimes even 'a kick in the ass' as they do not dare to take action on their own.

Michael (fifty-three), a former drug addict, had felt 'useless' after becoming clean: 'Look, all those years you're an addict, you stand still, or you even go backwards, because everyone is getting ahead except you.' He felt empowered by how his caseworker had given attention to this feeling before summoning him to volunteer. Talking to his welfare official about his experiences with drugs convinced Michael that his story could be helpful to others. As a volunteer, he could 'prevent others from making the same mistakes'. He could put his experience to use instead of feeling it will always be holding him back.

Caspar (fifty-nine) also felt empowered, when he could reciprocate the Salvation Army's former support with sorting out his overdue administration by volunteering at the Salvation Army's homeless shelter. He stated, 'I am being helped, so I can also do something in return, right?'

Experiences of support change workfare volunteers' notions of rights and duties over time. The gratitude people felt when they received help often changed their perspectives. At first many asked, 'Why should I help out as a volunteer when I need help myself?' But after receiving help, they often asked: 'I receive help, so why shouldn't I give something back?' (Kampen, 2014).

Doing volunteer work often intensified this feeling, especially when they felt others appreciated their work. This appreciation also helped to restore their violated life stories. Marcel (fifty-four) told us he had misused the hospitality of friends and family while being addicted to cocaine. After he quit drugs Marcel found peace in a volunteering job where he was taking children with intellectual disabilities to swimming lessons. He told us he routinely received compliments and often responded: 'If I can help someone, I will. ... That's the way I've always done it!' Confirmation of being able to help others pushed Marcel's former helplessness to the background. Being able to help others is an empowering experience in itself (Rappaport, 1987), and especially to those who received a lot of help in the past.

The experience of being needed also proved to be empowering, especially to those who felt written off. Andy (forty-two), who was made 'redundant' by his former boss, felt 'indispensable' after doing volunteer work for a couple of months. The appreciation he felt from his peers for his contributions as a volunteer changed his desire for work that would be 'profitable for himself' to a broader shared goal: 'it would be very unfair not to go to work' because 'they just count on me'.

Caseworkers turned out to also have a role in making people feel indispensable. Eric (fifty-five) felt recognised by the attention of his caseworker when he ended up in the hospital with intestinal complaints. Erik recounts: 
She immediately phoned me to ask how I was. I told her: 'Do you know that a whole new world has opened up for me, since you're my contact person?' She said: 'Why?' I said, 'I always felt like... I was a number. Now I feel that I am approached and treated as a real person.'

Before Eric's health was often a reason to keep his caseworker at a distance. As with many other welfare recipients, interest in their health often meant interest in their reasons for not working. Now, as a volunteer, Eric felt recognised by his caseworker's occasional inquiries about his health. While caseworkers may not be the most obvious persons to give this type of attention, our informants did not expect it from fellow volunteers. They thought their colleagues' attention should be directed elsewhere, towards those they are helping.

Summing up, many of our informants wished to restore their violated life stories and, when treated with respect, were able to do so by participating in volunteer work. They experienced volunteering as positive freedom (Berlin, 1969), as liberation from the worthlessness and humiliation they had previously felt. Other scholars have explained awarding positive freedom as a technology of agency operating to produce the desired or ethical citizen of advanced liberalism (McDonald and Marston, 2005; Muehlebach, 2012). They claim that people are made to feel worthless before offering them the chance to feel better. However, we found that positive freedom helps workfare clients to restore something essential that was broken before: their 'violated life stories'.

\section{Neglect of the future}

At first, being valued by others sufficed. However, after some time, when their violated life stories had been restored, they also wanted to be paid. After one or two years, workfare volunteers who functioned well in their positions again changed their perspective. They asked themselves: 'Now I am helping others, but who will help me?' Feeling useful and appreciated, their frame of reference changed. They started comparing themselves with paid colleagues and began wondering when they, too, would receive remuneration. Soraja (thirty-eight), for example, volunteered in a nursing home and thought she was 'ready for the next step'. 'Some people are volunteering there for ten years!', she told us, and she did not want to be 'one of those people'. She asked her caseworker and supervisors to support her in finding a paid job but did not get a positive response:

My supervisors tell me: 'You're not there yet, you have not learned enough yet.' But I cannot keep hearing that. I need to get paid, just like my supervisors.

Workfare volunteers turned to their caseworkers for recognition and direction, and expected them to prioritise paid jobs over volunteering. But most of them felt their caseworkers failed to offer such prospects. Ellen (thirty-seven) recounted: 'My caseworker tells me "Let's wait and see" ... but I have not heard from him since.' Ellen experienced a lack of commitment to her personal development. She needed confirmation that paid employment was within close reach. Like many others, Ellen did not find a regular job in the course of our research. Ellen eventually quit her volunteer work. Cynthia (forty-three), who enjoyed volunteering at an elderly day care but wanted to find a paid job again, also ran up against her caseworker's 'indifferent attitude': 
What am I supposed to focus on? That is something I've learned over the years, I have to focus on something or else I will never find a paid job. ... I expect help with this from him, but I don't get any.

Because of this lack of guidance, the empowering effects of volunteering turned sour and resulted in disempowerment.

When caseworkers displayed commitment towards their development it did make workfare volunteers feel empowered. On-the-job visits by caseworkers, for instance, were mentioned as an empowering experience. As long as they were treated seriously, and not visited abruptly or indiscreetly, workfare volunteers experienced caseworker visits as signs that their personal interests had not been forgotten. This fuelled the belief that volunteer work could eventually aid in finding paid employment. However, this type of empowering experience did not lead to employment.

In general, monitoring of workfare volunteers could be empowering as well as disempowering. When caseworkers just checked whether or not their client was still doing volunteer work, workfare volunteers felt disempowered. However, monitoring could also be empowering, provided it was part of a caseworker's involvement in their personal development. Such involvement confirmed feelings of being socially useful. More importantly, it recognised welfare clients' desire for brighter prospects. Instead of feeling that only they are held to account, they could feel that caseworkers were also accountable to them.

\section{Discussion and conclusions}

Proponents consider 'mandatory volunteering' as a contribution to employability, and empowerment, while critics dismiss it as stigmatising, disciplining, exploitative and disrupting personal freedom. Our study shows that both proponents and critics can be right, depending on four conditions.

First, even though our data confirm that workfare clients are indeed looking for freedom, contrary to critics' assumptions, workfare clients in our sample were primarily interested in positive rather than negative freedom: freedom to do something, rather than freedom from interference (Berlin, 1969). Workfare volunteering was appreciated when it gave them positive freedom: freedom to engage in meaningful activities, to help others and to develop new skills.

Second, our findings also show that the way caseworkers present the request to do volunteer work makes a lot of difference. Welfare clients in our sample generally felt empowered rather than disempowered, and experienced positive freedom, when treated with respect for their lives as narrative projects, including their failed projects and current hopes, in short: with respect for their 'violated life story' (Kampen, 2014). In the lives of many welfare clients, ventures had gone wrong, attempts had failed, and projects remained unfinished (e.g. Kroft et al., 1989). Many harboured a desire to redeem the past, to get back on track with life where they had left off. The key was for caseworkers to have an eye for people's violated life stories. However, when our respondents were approached in an impersonal, bureaucratic manner, they felt disempowered and bereft of freedom.

Paradoxically, some workfare volunteers in our sample sometimes even experienced being coerced as empowering, because it helped them to overcome feelings of anxiety. 
For most critical scholars, appreciation of coercion would be the ultimate sign of coercive authority (McDonald and Marston, 2005) and of disciplinary power 'creeping under the skin' (Cruikshank, 1999; Wiggan, 2015; Whitworth, 2016). However, in the light of their self-proclaimed biographies of hesitance and fear, particularly clients with anxiety disorders experienced coercion as a self-binding strategy that supported their striving for positive freedom.

Third, (dis)empowerment depended on workfare volunteers' own changing understandings of their past experiences. Our respondents themselves did not understand their predicament in the absolute terms that both critics and proponents assume. Instead, they understood their positions relative to their own pasts and imagined futures at different moments in time. Consequently, their experiences of workfare volunteerism also changed over time. Discipline could be experienced as empowering when unemployed individuals' pasts were considered, but could again become disempowering when their changing needs went unnoticed. Because of such changes over time, workfare policies can be exploitative or humiliating at one stage but empowering at another.

Fourth, the prospect of paid work is decisive for whether mandatory volunteering is (dis)empowering. This prospect is mostly lacking, which is the most pressing problem for workfare volunteers in our sample. This problem goes unnoticed by both critics and proponents of workfare volunteering. Over time, the restoration of violated life stories lost its empowering potential once it turned out that workfare volunteers' future prospects were neglected. The frame of comparison moved from the workfare volunteer's own past towards their current (paid) colleagues. At this point, the need to be remunerated increased. Without prospects for paid employment, volunteers began to feel misrecognised. Just like the goal of empowerment, the goal of employability turned sour over time. Clients often did become more employable, but that did not bring them employment. We therefore agree with the often raised criticism that activation without the reward of a paid job is humiliating and delegates the responsibility solely to the unemployed instead of (also) to the labour market, government and business (Wiggan, 2015; Whitworth, 2016).

These findings have broader implications for research into activation policies in developed welfare states. A diachronic approach is necessary, in order to flexibly attune to the changing needs of target groups. Such a diachronic approach includes the ways in which caseworkers approach the target group as well as how caseworkers pay attention to their personal histories, future goals and 'violated life stories'. Clients' experiences should be understood as relative to their own past, to colleagues and other relevant others, and to changes over time. This requires that policies and approaches of caseworkers also change over time in response to clients' changing needs and relative self-understanding.

\section{Acknowledgements}

We would like to thank David Hymans for editing this article.

\section{References}

Becker, U. (2000) 'Welfare state development and employment in the Netherlands in comparative perspective', Journal of European Social Policy, 10, 3, 219-39. 
Berlin, I. (1969) 'Four Essays on Liberty', New York: Oxford University Press, 118-72.

Bessant, J. (2000) 'Regulating the unemployed: Australia's work-for-the-dole scheme', Journal of Australian Studies, 24, 64, 75-84.

Bloom, H. S., Hill, C. J. and Riccio, J. A. (2003) 'Linking program implementation and effectiveness: lessons from a pooled sample of welfare-to-work experiments', Journal of Policy Analysis and Management, $22,4,551-75$.

Breitkreuz, R. (2005) 'Engendering citizenship? A critical feminist analysis of Canadian welfare-to-work policies and the employment experiences of lone mothers', Journal of Sociology and Social Welfare, $32,2,147-65$.

Cameron, A. (1997) 'In search of the voluntary sector: a review article', Journal of Social Policy, 26, 1, 79-88.

Clary, E. G., Snyder, M., Ridge, R. D., Copeland, J., Stukas, A. A., Haugen, J. and Miene, P. (1998) 'Understanding and assessing the motivations of volunteers: a functional approach', Journal of Personality and Social Psychology, 74, 6, 1516-30.

Cockram, J. (2002) Volunteering and Community Participation by Jobless People, Perth, WA: Volunteering Western Australia.

Cohen, A. (2009) 'Welfare clients' volunteering as a means of empowerment', Nonprofit and Voluntary Sector Quarterly, 38, 3, 522-34.

Cox, R. (1998) 'From safety net to trampoline: labor market activation in the Netherlands and Denmark', Governance, 11, 4, 397-414.

Cress, D., McPherson, J. and Rotolo, T. (1997) 'Competition and commitment in voluntary memberships: the paradox of persistence and participation', Sociological Perspectives, 40, 1, 61-79.

Crick, B. (2000) Essays on Citizenship, London: Bloomsbury Publishing.

Cruikshank, B. (1999) The Will to Empower: Democratic Citizens and Other Subjects, Ithaca: Cornell University Press.

Dean, H. (2015) Social Rights and Human Welfare, London: Routledge.

Dean, M. (1999) Governmentality: Power and Rule in Modern Society, London: Sage.

Dwyer, P., Hodkinson, S., Lewis, H. and Waite, L. (2016) 'Socio-legal status and experiences of forced labour among asylum seekers and refugees in the UK', Journal of International and Comparative Social Policy, 32, 3, 182-98.

Edmiston, D. (2017) 'Welfare, austerity and social citizenship in the UK', Social Policy and Society, 16, 2, 261-70.

Edmiston, D., Patrick, R. and Garthwaite, K. (2017) 'Introduction: austerity, welfare and social citizenship', Social Policy and Society, 16, 2, 253-59.

Foucault, M. (2003) 'Governmentality', in P. Rabinow and N. Rose (eds.), The Essential Foucault: Selections from the Essential Works of Foucault, 1954-1984. New York: New Press.

Fuller, S., Kershaw, P. and Pulkingham, J. (2008) 'Constructing "active citizenship": single mothers, welfare, and the logics of voluntarism', Citizenship Studies, 12, 2, 157-76.

Garthwaite, K. (2017) 'I feel I'm giving something back to society': constructing the 'active citizen' and responsibilising foodbank use', Social Policy and Society, 16, 2, 283-92.

Gilbert, N. (2002) Transformation of the Welfare State: The Silent Surrender of Public Responsibility, Oxford: Oxford University Press.

Gilbert, N. and Gilbert, B. (1989) The Enabling State: Modern Welfare Capitalism in America, Oxford: Oxford University Press.

Goul Andersen, J. (2002) 'Coping with long-term unemployment: economic security, labour market integration and well-being. Results from a Danish panel study, 1994-1999', International Journal of Social Welfare, 11, 3, 178-90.

Goul Andersen, J., Guillemard, A., Jensen, P. and Pfau Effinger, B. (2005) The Changing Face of Welfare: Consequences and Outcomes from a Citizenship Perspective, Bristol: Policy Press.

Hall, G., Boddy, J., Chenoweth, L. and Davie, K. (2012) 'Mutual benefits: developing relational service approaches within centrelink', Australian Social Work, 65, 87-103. 
Kampen, T. (2014) Verplicht Vrijwilligerswerk: De Ervaringen van Bijstandscliënten met een Tegenprestatie voor hun Uitkering, Amsterdam: Van Gennep.

Kampen, T., Elshout, J. and Tonkens, E. (2013) 'The fragility of self-respect: emotional labour of workfare volunteering', Social Policy and Society, 12, 427-38.

Kjørstad, M. (2005) 'Between professional ethics and bureaucratic rationality: the challenging ethical position of social workers who are faced with implementing a workfare policy', European Journal of Social Work, 8, 381-98.

Knijn, T. and Van Berkel, R. (2003) 'Again revisited: employment and activation policies for lone parents in the Netherlands', in J. Millar and M. Evans (eds.), Lone Parents' Employment: International Comparisons of What Works, London: DWP.

Koen, J. (2013) Prepare and Pursue: Routes to Suitable (Re-) Employment, Dissertation: University of Amsterdam.

Kroft, H., Engbersen, G., Schuyt, K. and Van Waarden, F. (1989) Een Tijd Zonder Werk: Een Onderzoek naar de Belevingswereld van Langdurig Werklozen, Leiden: Stenfert Kroese.

Levy, M. (2006) 'Volunteering for the dole: good or bad?', Australian Journal on Volunteering, 11, 1, $38-49$.

McClure, P. (2000) Participation Support for a More Equitable Society: Final Report of the Reference Group on Welfare Reform, Canbarra, Australia: Department of Family and Community Services.

McDonald, C. and Marston, G. (2005) 'Workfare as welfare: governing unemployment in the advanced liberal state', Critical Social Policy, 25, 3, 374-401.

Mead, L. (2008) Beyond Entitlement, New York: Simon and Schuster.

Miller, P. and Rose, N. (2008) Governing the Present: Administering Economic, Social and Personal Life, Bristol: Polity Press.

Muehlebach, A. (2012) The Moral Neoliberal: Welfare and Citizenship in Italy, Chicago: University of Chicago Press.

Nannestad, P. (2007) 'Immigration and welfare states: a survey of 15 years of research', European Journal of Political Economy, 23, 2, 512-32.

Nothdurfter, U. (2016) 'The street-level delivery of activation policies: constraints and possibilities for a practice of citizenship', European Journal of Social Work, 19, 420-40.

Owen, D. (1996) 'Dilemmas and opportunities for the young active citizen', Youth Studies Australia, 15, 1, 20-3.

Patrick, R. (2014) 'Working on welfare: findings from a qualitative longitudinal study into the lived experiences of welfare reform in the UK', Journal of Social Policy, 43, 4, 705-25.

Patrick, R. (2017) For Whose Benefit?: The Everyday Realities of Welfare Reform, Chicago: Policy Press.

Povey, L. (2017) 'Where welfare and criminal justice meet: applying Wacquant to the experiences of marginalised women in austerity Britain', Social Policy and Society, 16, 2, 271-81.

Rappaport, J. (1987) 'Terms of empowerment/exemplars of prevention: toward a theory for community psychology', American Journal of Community Psychology, 15, 121-48.

Reitsma-Street, M., Maczewski, M. and Neysmith, S. (2000) 'Promoting engagement: an organizational study of volunteers in community resource centres for children', Children and Youth Services Review, $22,8,651-78$.

Roberts, J. and Devine, F. (2004) 'Some everyday experiences of voluntarism: social capital, pleasure, and the contingency of participation', Social politics, 11, 2, 280-96.

Serrano Pascual, A. (2007) 'Activation regimes in Europe: a clustering exercise', in A. Serrano Pascual and L. Magnusson (eds.), Reshaping Welfare States and Activation Regimes in Europe, Brussels: Peter Lang.

Serrano Pascual, A. and Magnusson, L. (2007) Reshaping Welfare States and Activation Regimes in Europe, Brussels: Peter Lang.

Skevik, A. (2005) 'Women's citizenship in the time of activation: the case of lone mothers in "needs-based" welfare states', Social Politics, 12, 1, 42-66.

Sobus, M. S. (1995) 'Mandating community service: psychological implications of requiring prosocial behavior', Law and Psychological Review, 19, 153-182. 
Soupourmas, F. and Ironmonger, D. (2002) Giving Time. The Economic and Social Value of Volunteering in Victoria, Melbourne, Australia: Department of Human Services.

Stukas, A., Snyder, M. and Clary, E. (1999) 'The effects of 'mandatory volunteerism' on intentions to volunteer', Psychological Science, 10, 1, 59-64.

Thoits, P. and Hewitt, L. (2001) 'Volunteer work and social well-being', Journal of Health and Social Behavior, 48, 174-87.

Van Echteld, P. and Josten, E. (2012) 'Werken voor je geld', in V. Veldheer, J. Jonker, L. van Noije and C. Vrooman (2012) Een Beroep op de Burger. Minder Verzorgingsstaat, Meer Eigen Verantwoordelijkheid? Sociaal en Cultureel Rapport 2012, The Hague: Sociaal en Cultureel Planbureau.

Van Houwelingen, P., Boele, A. and Dekker, P. (2014) Burgermacht op Eigen Kracht? Een Brede Verkenning van Ontwikkelingen in Burgerparticipatie, The Hague: Sociaal en Cultureel Planbureau.

Veldheer, V., Jonker, J., van Noije, L. and Vrooman, C. (2012) Een Beroep op de Burger. Minder Verzorgingsstaat, Meer Eigen Verantwoordelijkheid? Sociaal en Cultureel Rapport 2012. The Hague: Sociaal en Cultureel Planbureau.

Warburton, J. and Smith, J. (2003) 'Out of the generosity of your heart: are we creating active citizens through compulsory volunteer programmes for young people in Australia?', Social Policy and Administration, 37, 772-86.

Whitworth, A. (2016) 'Neoliberal paternalism and paradoxical subjects: confusion and contradiction in UK activation policy', Critical Social Policy, 36, 3, 412-31.

Wiggan, J. (2015) 'Reading active labour market policy politically: an autonomist analysis of Britain's Work Programme and Mandatory Work Activity', Critical Social Policy, 35, 3, 369-92.

Yeatman, A. (2000) 'Mutual obligation: what kind of contract is this?' in S. Shaver and P. Saunders (eds.), Reforming the Australian Welfare State, Melbourne, Australia: Australian Institute of Family Studies. 